\title{
Effect of Phosphate-Solubilizing Bacteria on the Mobility of Insoluble Cadmium and Metabolic Analysis
}

\author{
Ping Yang, Xue-Fang Zhou, Li-Li Wang, Qu-Sheng Li *, Ting Zhou, Yu-Kun Chen, Zi-Yi Zhao \\ and Bao-Yan He \\ School of Environment, Jinan University, Guangzhou 511443, China; yangp35@jnu.edu.cn (P.Y.); \\ fangzhouujn@163.com (X.-F.Z.); wanglili@jnu.edu.cn (L.-L.W.); 1534281009@stu2015.jnu.edu.cn (T.Z.); \\ 13424468075@163.com (Y.-K.C.); 15521384003@163.com (Z.-Y.Z.); thbyan@jnu.edu.cn (B.-Y.H.) \\ * Correspondence: liqusheng@21cn.com; Tel.: +86-20-8522-7987; Fax: +86-20-8522-6615
}

Received: 4 June 2018; Accepted: 22 June 2018; Published: 25 June 2018

\begin{abstract}
Phosphate-solubilizing bacteria (PSB) can promote plant growth by dissolving insoluble phosphate. Therefore, PSB may have the potential to improve the mobility of heavy metals in soils and enhance phytoextraction. This study isolated a few PSB strains that could dissolve $\mathrm{CdCO}_{3}$ and solid Cd in soil. Two typical PSB, namely, high- and low-Cd-mobilizing PSB (Pseudomonas fluorescens gim-3 and Bacillus cereus qh-35, respectively), were selected to analyze the metabolic profiles, metabolic pathways, and mechanisms of mobilization of insoluble Cd. A total of 34 metabolites secreted by the two PSB strains were identified. Gluconic acid was the main contributor to Cd dissolution (42.4\%) in high-Cd-mobilizing PSB. By contrast, gluconic acid was not secreted in low-Cd-mobilizing PSB. Metabolic pathway analysis showed that gluconic acid was produced by the peripheral direct oxidation pathway. Hence, PSB with peripheral direct oxidation pathway were likely to have high-Cd-mobilizing capacity.
\end{abstract}

Keywords: phosphate-solubilizing bacteria; cadmium-mobilizing bacteria; metabolic pathway; organic acid

\section{Introduction}

Cadmium or cadmium compounds can increase the risk of lung cancer, kidney lesions, and bone damage [1-4]. Cadmium in soil can be assimilated by crops; because of which, it enters the human body through the food chain and adversely affects human health. Phytoextraction is an ecologically friendly and cost-effective technique that can be used to remove C $\mathrm{d}$ from contaminated soils [5-8]. However, this process suffers from some limitations, such as the low mobility of the tightly bound fraction of $\mathrm{Cd}$ in soils with neutral $\mathrm{pH}$, resulting in reduced uptake by plants [9].

To address such limitations, scientists have developed bacterium-assisted phytoextraction, in which bacteria are added to soil to facilitate Cd phytoextraction [10-14]. Bacteria such as Bacillus pumilus E2S2 increased Sedum plumbizincicola Cd uptake (43\%) [15], and Pseudomonas sp. Lk9 increased Cd uptake (46.6\%) of Solanum nigrum L. in multi-metal contaminated soil [16]. The added bacteria usually need to promote plant growth and increase the amount of metals absorbed by the tested plants $[17,18]$. Several studies have employed bacteria that were selected or tested for the presence of the enzyme 1-aminocyclopropane-1-carboxylate deaminase and the ability to synthesize indole-3-acetic acid and siderophores [19-22]. Nevertheless, few studies have investigated the potential role of an active phosphate solubilization system in bacteria in promoting heavy metal solubilization in soil. It has been reported that phosphate fertilizer can improve the phytoextraction efficiency of $\mathrm{Cd}$ by Sedum [23]. 
Phosphate-solubilizing bacteria (PSB) can improve plant growth in contaminated soils by supplying macronutrient phosphorus and are thus beneficial to $\mathrm{Cd}$ remediation [24]. PSB dissolves inorganic phosphates by secreting organic acids [25-27]. These organic acids enhance phosphate solubility by ionizing protons to decrease the $\mathrm{pH}$ and to combine $\mathrm{PO}_{4}{ }^{3-}$ to form $\mathrm{HPO}_{4}{ }^{2-}$ or $\mathrm{H}_{2} \mathrm{PO}_{4}{ }^{-}$. Organic acid anions can also form a complex with metal cations $\left(\mathrm{Ca}^{2+}, \mathrm{Al}^{3+}\right.$, and $\left.\mathrm{Fe}^{3+}\right)$ and consequently, release $\mathrm{PO}_{4}{ }^{3-}$. In the same way, PSB-assisted phytoextraction may improve the mobility of $\mathrm{Cd}$ in soil, which has been reported by several studies [28,29]. For example, endophytic Rahnella sp. JN6 effectively solubilized $8.8 \mathrm{mg} / \mathrm{L} \mathrm{Cd}$ and $133.54 \mathrm{mg} / \mathrm{L}$ phosphate in a culture solution and enhanced Cd accumulation in Brassica napus [30]. Burkholderia sp. J62 solubilized $25.8 \mathrm{mg} / \mathrm{L} \mathrm{Cd}$ and $234 \mathrm{mg} / \mathrm{L}$ phosphate in a culture solution and increased the biomass of maize and tomato plants [31]. Decreases of the $\mathrm{pH}$ values in the culture solutions were considered their causes. However, the dissolving amount of cadmium was different at similar $\mathrm{pH}$ values in these studies. To our knowledge, organic acids of different types and quantities can dissolve varying amounts of phosphate and $\mathrm{Cd}[32,33]$. So, we needed to identify the secreted organic acids to explain the differences in the insoluble $\mathrm{Cd}$ dissolved by different strains. Furthermore, the metabolic mechanisms involved in the production of these organic acids must be elucidated.

The present study aimed to (1) investigate the effects of PSB on $\mathrm{CdCO}_{3}$ solubility and Cd mobilization in soil collected from a Cd-polluted field; (2) research the differences between the secretions of high- and low-Cd-mobilizing PSB; and (3) explain the differences in the metabolic pathways of high- and low-Cd-mobilizing PSB.

\section{Material and Methods}

\subsection{PSB Isolation and $C d$ Solubility Tests}

Soils were collected from a vegetable field located in a suburb of Guangzhou. The soil was polluted with $\mathrm{Cd}$ because of sewage irrigation 20 years ago. The soil properties were as follows: $\mathrm{pH}, 6.86 \pm 0.11$; total P, $2005.2 \pm 58.8 \mathrm{mg} / \mathrm{kg}$; available P, $94.0 \pm 1.2 \mathrm{mg} / \mathrm{kg}$; available N, $118.5 \pm 5.3 \mathrm{mg} / \mathrm{kg}$; organic C, $35.4 \pm 1.2 \mathrm{~g} / \mathrm{kg}$; cation exchange capacity (CEC), $30.6 \pm 1.1 \mathrm{cmol} / \mathrm{kg}$; and total Cd, $1.952 \pm 0.084 \mathrm{mg} / \mathrm{kg}$. The speciation of $\mathrm{Cd}$, as determined by the Tessier method [34], in the soil was as follows: exchangeable, $0.286 \mathrm{mg} / \mathrm{kg}$; bound to carbonates, $0.239 \mathrm{mg} / \mathrm{kg}$; bound to Fe-Mn oxides, $0.486 \mathrm{mg} / \mathrm{kg}$; bound to organic matter, $0.189 \mathrm{mg} / \mathrm{kg}$; and residual, $0.851 \mathrm{mg} / \mathrm{kg}$.

Briefly, $10 \mathrm{~g}$ of soil was mixed with $90 \mathrm{~mL}$ of sterile water and shaken for $1 \mathrm{~h}$ to extract bacteria from the $\mathrm{Cd}$-contaminated soil. Suitable dilutions were inoculated using a phosphate-solubilizing test agar medium containing (per liter) $10 \mathrm{~g}$ of glucose, $5 \mathrm{~g}$ of $\mathrm{Ca}_{3}\left(\mathrm{PO}_{4}\right)_{2}, 0.3 \mathrm{~g}$ of NaCl, $0.5343 \mathrm{~g}$ of $\mathrm{MgSO}_{4} \cdot 7 \mathrm{H}_{2} \mathrm{O}, 0.0227 \mathrm{~g}$ of $\mathrm{MnSO}_{4} \cdot \mathrm{H}_{2} \mathrm{O}, 0.3 \mathrm{~g}$ of $\mathrm{KCl}, 0.5 \mathrm{~g}$ of $\left(\mathrm{NH}_{4}\right)_{2} \mathrm{SO}_{4}, 0.03 \mathrm{~g}$ of $\mathrm{FeSO}_{4} \cdot 7 \mathrm{H}_{2} \mathrm{O}$, and $15 \mathrm{~g}$ of agar. The $\mathrm{pH}$ of the agar medium was adjusted to $\mathrm{pH} 7.0$. After 7 days of plate incubation at $28{ }^{\circ} \mathrm{C}$, colonies with clear halos considered to be PSB were counted. The predominant colonies were purified through re-streaking on a phosphate-solubilizing test agar plate.

Bacterial isolates were cultured in $50 \mathrm{~mL}$ of phosphate-solubilizing test liquid medium supplemented with $0.06 \mathrm{~g} / \mathrm{L} \mathrm{CdCO} 3(39.1 \mathrm{mg} / \mathrm{L} \mathrm{Cd}), 0.668 \mathrm{~g} / \mathrm{L} \mathrm{Ca}_{3}\left(\mathrm{PO}_{4}\right)_{2}$, and $1 \mathrm{~g} / \mathrm{L}$ glucose (as nutrient-rich medium) or $0.06 \mathrm{~g} / \mathrm{L} \mathrm{CdCO} 3(39.1 \mathrm{mg} / \mathrm{L} \mathrm{Cd}), \mathrm{Ca}_{3}\left(\mathrm{PO}_{4}\right)_{2} 0.334 \mathrm{~g} / \mathrm{L}$, glucose $1 \mathrm{~g} / \mathrm{L}$, and $10 \%$ concentration of the corresponding inorganic salts (as nutrient-poor medium). The inoculated media were incubated for $1,3,5$, and 7 days on a rotary shaker at $28^{\circ} \mathrm{C}$, respectively. The mobility of the cadmium showed obvious differences between day 1 and day 7 , so we took these two treatments to conduct follow-up tests. A separate liquid medium inoculated with sterile water served as the control treatment. Three replicates were used for each experiment. After the culture solution was centrifuged at $1800 \times g$ for $10 \mathrm{~min}$, the supernatant was passed through a $0.22 \mu \mathrm{m}$ filter. A part of each filtrate was used as sample for gas chromatography-mass spectrometry (GC-MS) determination, and the other part was used for measuring $\mathrm{pH}$ and solubilized $\mathrm{P}$ and $\mathrm{Cd}$ concentrations. The $\mathrm{pH}$ of each filtrate was measured using a $\mathrm{pH}$ meter. Solubilized $\mathrm{P}$ concentration was measured by colorimetric Mo-blue 
method, using UV mini-1240 UV-Vis spectrophotometer (Shimadzu, Kyoto, Japan). The concentration of soluble Cd was determined by an atomic absorption spectrometer in flame mode (AAS, PerkinElmer, Waltham, MA, USA). A total of 10 bacterial strains that can simultaneously dissolve phosphate and cadmium carbonate were screened (data not shown). The PSB with the highest (strain gim-3) and lowest (strain qh-35) dissolved cadmium concentrations were selected for 16S rDNA gene sequencing, which was conducted by the BGI GROUP, Guangzhou, China. The $16 \mathrm{~S}$ rDNA sequence showed that strain qh-35 was very closely related to B. cereus and strain gim-3 was very closely related to $P$. fluorescens (Text S1 and Text S2,). Strain qh-35 was gram-positive. Its colonies were small, suborbicular, and the colony surface was smooth and transparent (Figure S1). Strain gim-3 was gram-negative. Its colonies were small, round, and opaque with a white spot. The colony surface was moist and flat (Figure S2). Subsequently, physiological, and biochemical tests were conducted using an API 50 CHB, API 20 E, and API 20 NE system (Biomerieux, Marcy-l'Étoile, France) (Tables S1 and S2).

\subsection{Effects of PSB on Cd Mobility in Contaminated Soil}

Pure bacterial isolates (B. cereus or P. fluorescens) were cultivated in $100 \mathrm{~mL}$ of nutrient-rich medium containing $1 \mathrm{~g}$ of sterile Cd-polluted soil on a rotary shaker at $28^{\circ} \mathrm{C}$. A control sample was prepared by adding the same amount of sterile water instead of bacterial inoculate. After 1 or 7 days of incubation, the soil suspensions were centrifuged at $1800 \times g$ for $10 \mathrm{~min}$ and filtered. The $\mathrm{Cd}$ concentration in the filtrate was measured by atomic absorption spectroscopy (AAS).

\subsection{Determination of PSB Secretions and Organic Acids}

The experimental process referred to some literature $[35,36]$. Each culture filtrate sample $(0.5 \mathrm{~mL})$ of the $\mathrm{CdCO}_{3}$ solubility tests was added to test tubes and freeze dried. The dried residue was derivatized by $20 \mu \mathrm{L}$ of methoxyamine hydrochloride $\left(20 \mathrm{mg} / \mathrm{mL}\right.$ in pyridine at $37^{\circ} \mathrm{C}$ for $\left.2 \mathrm{~h}\right)$ and $70 \mu \mathrm{L} \mathrm{N}$-methyl- $\mathrm{N}$-(trimethylsilyl) trifluoroacetamide (at $37^{\circ} \mathrm{C}$ for $30 \mathrm{~min}$ ). Then, n-hexane $(410 \mu \mathrm{L}$ ) was added to form a total volume of $0.5 \mathrm{~mL}$.

Samples $(1 \mu \mathrm{L})$ were injected into a gas chromatography (GC) (GC-2010 Plus, Shimadzu, Kyoto, Japan) in splitless mode by an autosampler (AOC-20s, Shimadzu, Kyoto, Japan) and autoinjector (AOC-20i, Shimadzu, Kyoto, Japan). GC analysis was carried out on a Rxi-5MS with a capillary column $(30 \mathrm{~m} \times 0.25 \mathrm{~mm} \times 0.25 \mu \mathrm{m}$, Thermo Fisher, Waltham, MA, USA). The injection, interface, and ion-source temperatures were adjusted to $230{ }^{\circ} \mathrm{C}, 250^{\circ} \mathrm{C}$, and $220^{\circ} \mathrm{C}$, respectively. The helium flow rate was $1 \mathrm{~mL} / \mathrm{min}$. The column temperature was controlled as follows: maintained for $1 \mathrm{~min}$ at $70{ }^{\circ} \mathrm{C}$, ramped to $76{ }^{\circ} \mathrm{C}$ in $6 \mathrm{~min}$, then ramped to $300{ }^{\circ} \mathrm{C}$ in $44.8 \mathrm{~min}$, and held for $10 \mathrm{~min}$ at $300{ }^{\circ} \mathrm{C}$. The column end was introduced into a quadrupole electron impact ionization mass spectrometer (GCMS-QP2010 Ultra, Shimadzu, Kyoto, Japan). Mass spectra were recorded at 2 scans $/ \mathrm{s}$ under $\mathrm{m} / \mathrm{z}$ 50-600 scanning range.

The raw GC-MS chromatogram was automatically analyzed using the automatic mass spectral deconvolution and identification system (AMDIS) and compared with the NIST05 database [37,38]. If the similarity was greater than $80 \%$ and the retention index difference was less than 20 , then the compounds were identified $[39,40]$. The retention index was obtained by measuring the retention time of n-alkanes $(0.5 \mu \mathrm{L}$, n-alkane C8-C40, SUPELCO, Bellefonte, PA, USA) in the blank solution.

All secreted organic acids were quantified by the method of internal standard method [41,42]. The peak area was extracted and calculated using metabolomics ion-based data extraction algorithm (MET-IDEA), which selected the first or second strong peak as the mark peak (Table S3).

\subsection{The Ability of PSB-Secreted Organic Acids to Solubilize Cd}

To determine the Cd-solubilizing ability of the detected organic acids, $10 \mathrm{mg}$ of $\mathrm{CdCO}_{3}$ and $20 \mathrm{~mL}$ of a series of organic acid solutions with different concentrations were added into a $50 \mathrm{~mL}$ tube. The mixture was shaken for 1 day at room temperature. A control was prepared by adding the same amount of sterile water instead of organic acid solution. Three replicates were used for each 
experiment. After the solution was centrifuged at $1800 \times \mathrm{g}$ for $10 \mathrm{~min}$ and filtered, the $\mathrm{Cd}$ concentration in the filtrate was measured by AAS. A relationship between $\mathrm{Cd}$ concentration and organic acid concentration was established. A curve showing the cadmium-solubilizing ability $\left(\mathrm{CdCO}_{3}\right)$ of each organic acid tested is presented in Figure S3. The Cd concentration dissolved by organic acids secreted from bacteria can be calculated based on this curve.

\subsection{Statistical Analysis}

Statistical analysis was conducted using SPSS (IBM, Armonk, NY, USA) 19. Data were tested at significance levels of $p<0.05$ by independent-sample Mann-Whitney U test (for non-parametric test), student's t-test (for two samples), and ANOVA Duncan test (for three or more samples).

\section{Results and Discussion}

\subsection{Effects of PSB on Solubilization of $C d$ Carbonate in Liquid Medium}

Table 1 shows the effects of Bacillus cereus and Pseudomonas fluorescens on the solubility of cadmium and phosphate. Both of them not only dissolved a considerable amount of phosphate but also solubilized $\mathrm{Cd}$ carbonate. After the strains were incubated in the liquid medium for 1 and 7 days, the fraction of dissolved $\mathrm{Cd}$ increased from $9.4 \%$ to $92 \%$. In addition, P. fluorescens was superior to B. cereus in solubilizing Cd. Therefore, we designated P. fluorescens and B. cereus as high- and low-Cd-mobilizing PSB, respectively.

B. cereus grew well in the nutrient-rich medium. The dissolving amount of phosphate and Cd increased with the increase of incubation time. The amount of dissolved Cd was $16.9 \mathrm{mg} / \mathrm{L}(43.3 \%)$ on the first day and increased to $20.0 \mathrm{mg} / \mathrm{L}(51.2 \%)$ after 7 days. The $\mathrm{pH}$ of the solution decreased from 6.24 to 5.38. By contrast, the growth and Cd-dissolving ability of the strain were restrained in the nutrient-poor medium because of insufficient nutrients. The levels of dissolved Cd were $4.4 \mathrm{mg} / \mathrm{L}$ $(11.3 \%)$ and $5.34 \mathrm{mg} / \mathrm{L}(13.7 \%)$ on days 1 and 7 , respectively, and the $\mathrm{pH}$ did not change.

$P$. fluorescens also grew well in the nutrient-rich medium. But the growth rate of $P$. fluorescens was faster than that of B. cereus. So, the amounts of dissolved phosphate and $\mathrm{Cd}(23.0 \mathrm{mg} / \mathrm{L}$ and $76.6 \%$ ) reached high values on day 1 . After 7 days of incubation, the bacteria died, disintegrated, and adsorbed dissolved Cd, thereby decreasing the Cd concentration to $12.0 \mathrm{mg} / \mathrm{L} \mathrm{(30.7 \% ).} \mathrm{The} \mathrm{pH}$ increased from 5.00 to 6.36. In the nutrient-poor medium, bacterial growth was delayed because of insufficient nutrients. The amount of dissolved Cd was $5.18 \mathrm{mg} / \mathrm{L}(13.3 \%)$ on the first day and increased to $36.0 \mathrm{mg} / \mathrm{L}$ (92.3\%) after 7 days. The $\mathrm{pH}$ decreased from 6.28 to 4.09 .

PSB dissolved inorganic phosphate mainly by acidification. Thus, PSB can facilitate the mobility and bioavailability of heavy metals in soils. Similarly, the addition of Pseudomonas sp. TLC 6-6.5-4 to the Bushnell Hass (BH) medium supplemented with $\mathrm{CuCO}_{3}$ solubilized $41.8 \mathrm{mg} / \mathrm{L} \mathrm{Cu}$ and decreased the $\mathrm{pH}$ value from 7 to 4.9 [43]. Previous studies had documented that acidification of bacteria had a good effect on the solubility and phytoextraction of $\mathrm{Cd}[30,31]$. Our results also showed that the concentrations of dissolved phosphate and $\mathrm{Cd}$ were inversely related to the $\mathrm{pH}$ value. With the $\mathrm{pH}$ value from 6.49 to 4.09 in different media of two strains, the amount of cadmium dissolved from $4.40 \mathrm{mg} / \mathrm{L}$ to $36.0 \mathrm{mg} / \mathrm{L}$. 
Table 1. Effect of B. cereus and P. fluorescens on the solubility of cadmium $\left(\mathrm{CdCO}_{3}\right)$ and phosphate $\left(\mathrm{Ca}_{3}\left(\mathrm{PO}_{4}\right)_{2}\right)$.

\begin{tabular}{|c|c|c|c|c|c|c|c|c|}
\hline \multirow{2}{*}{ Treatment } & \multicolumn{4}{|c|}{1 Day } & \multicolumn{4}{|c|}{7 Days } \\
\hline & $\mathrm{PO}_{4}{ }^{3-}(\mathrm{mg} / \mathrm{L})$ & $\mathrm{Cd}^{2+}(\mathrm{mg} / \mathrm{L})$ & $\begin{array}{c}\mathrm{Cd}^{2+} \\
\text { Dissolution } \\
\text { Rate (\%) }\end{array}$ & $\mathrm{pH}$ & $\mathrm{PO}_{4}{ }^{3-}(\mathrm{mg} / \mathrm{L})$ & $\mathrm{Cd}^{2+}(\mathrm{mg} / \mathrm{L})$ & $\begin{array}{c}\mathrm{Cd}^{2+} \\
\text { Dissolution } \\
\text { Rate (\%) }\end{array}$ & $\mathrm{pH}$ \\
\hline B. cereus ${ }^{1}$ & $6.16 \pm 0.17^{\mathrm{bA}}$ & $16.94 \pm 0.80^{\mathrm{bA}}$ & 43.32 & $6.24 \pm 0.05^{\mathrm{bB}}$ & $10.06 \pm 0.90^{\mathrm{bB}}$ & $20.03 \pm 1.42 \mathrm{~dB}$ & 51.23 & $5.38 \pm 0.24^{\mathrm{bA}}$ \\
\hline P. fluorescens 1 & $31.82 \pm 2.13 \mathrm{cA}$ & $29.96 \pm 2.84 \mathrm{cB}$ & 76.62 & $5.00 \pm 0.11^{\mathrm{aA}}$ & $30.55 \pm 1.34^{\mathrm{cA}}$ & $12.00 \pm 0.77 \mathrm{cA}$ & 30.69 & $6.36 \pm 0.05^{\mathrm{cB}}$ \\
\hline B. cereus $^{2}$ & $4.31 \pm 0.19 \mathrm{abA}$ & $4.40 \pm 0.15^{\mathrm{aA}}$ & 11.26 & $6.49 \pm 0.03 \mathrm{cA}$ & $4.04 \pm 0.20 \mathrm{aA}$ & $5.34 \pm 0.11^{\mathrm{bB}}$ & 13.66 & $6.43 \pm 0.06^{\mathrm{cA}}$ \\
\hline P. fluorescens ${ }^{2}$ & $4.66 \pm 0.23^{\mathrm{abA}}$ & $5.18 \pm 0.04^{\mathrm{aA}}$ & 13.26 & $6.28 \pm 0.03^{b B}$ & $64.27 \pm 2.45^{\mathrm{dB}}$ & $35.98 \pm 0.56^{\mathrm{eB}}$ & 92.03 & $4.09 \pm 0.33^{\mathrm{aA}}$ \\
\hline control & $3.69 \pm 0.30^{\mathrm{aA}}$ & $2.87 \pm 0.24^{\mathrm{aA}}$ & 7.34 & $6.71 \pm 0.04 \mathrm{~dB}$ & $3.76 \pm 0.32^{\mathrm{aA}}$ & $3.68 \pm 0.35^{\mathrm{aB}}$ & 9.41 & $6.54 \pm 0.04^{\mathrm{cA}}$ \\
\hline
\end{tabular}

The superscript ${ }^{1}$ indicates $100 \%$ liquid phosphate-solubilizing functional medium (pH 7.0-7.5) (called nutrient-rich medium) containing 0.3 g/L NaCl, $0.5343 \mathrm{~g} / \mathrm{L} \mathrm{MgSO}{ }_{4} \cdot 7 \mathrm{H}_{2} \mathrm{O}$ $0.0227 \mathrm{~g} / \mathrm{L} \mathrm{MnSO}_{4} \cdot \mathrm{H}_{2} \mathrm{O}, 0.3 \mathrm{~g} / \mathrm{L} \mathrm{KCl}, 0.5 \mathrm{~g} / \mathrm{L}\left(\mathrm{NH}_{4}\right)_{2} \mathrm{SO}_{4}, 0.03 \mathrm{~g} / \mathrm{L} \mathrm{FeSO}_{4} \cdot 7 \mathrm{H}_{2} \mathrm{O}, 1 \mathrm{~g} / \mathrm{L}$ glucose, $0.668 \mathrm{~g} / \mathrm{L} \mathrm{Ca}_{3}\left(\mathrm{PO}_{4}\right)_{2}$, and $0.06 \mathrm{~g} / \mathrm{L} \mathrm{CdCO} 3(39.1 \mathrm{mg} / \mathrm{L} \mathrm{Cd})$. The superscript ${ }^{2}$ was $10 \%$ liquid phosphate-solubilizing functional medium ( $\mathrm{pH}$ 7.0-7.5) (called nutrient-poor medium) containing $0.03 \mathrm{~g} / \mathrm{L} \mathrm{NaCl}, 0.05343 \mathrm{~g} / \mathrm{L} \mathrm{MgSO} \cdot 7 \mathrm{H}_{2} \mathrm{O}, 0.00227 \mathrm{~g} / \mathrm{L} \mathrm{MnSO} \cdot \mathrm{H}_{2} \mathrm{O}, 0.03 \mathrm{~g} / \mathrm{L}$ $\mathrm{KCl}, 0.05 \mathrm{~g} / \mathrm{L}\left(\mathrm{NH}_{4}\right)_{2} \mathrm{SO}_{4}, 0.003 \mathrm{~g} / \mathrm{L} \mathrm{FeSO}{ }_{4} \cdot 7 \mathrm{H}_{2} \mathrm{O}, 1 \mathrm{~g} / \mathrm{L}$ glucose, $0.334 \mathrm{~g} / \mathrm{L} \mathrm{Ca}_{3}\left(\mathrm{PO}_{4}\right)_{2}$, and $0.06 \mathrm{~g} / \mathrm{L} \mathrm{CdCO}_{3}(39.1 \mathrm{mg} / \mathrm{L} \mathrm{Cd})$. Data include mean \pm standard deviation $(S D)$ of three replicates $(n=3)$. Different small letters in each column indicate significant differences at the $p<0.05$ level in accordance with the ANOVA Duncan test. Different capital letters in each row indicate that the $\mathrm{pH}$ and $\mathrm{PO}_{4}{ }^{3-}$ and $\mathrm{Cd}^{2+}$ concentrations at days 1 and 7 were significantly different at $p<0.05$ in accordance with student's $t$ test. 


\subsection{Effects of Cd-Mobilizing PSB on Mobility of Soil Cd}

Table 2 showed the effects of PSB on Cd mobility in Cd-polluted soil. In P. fluorescens, after the control data were deducted, 0.18 and $0.39 \mathrm{mg} / \mathrm{kg} \mathrm{Cd}$ were dissolved in the 1- and 7-day culture. These amounts accounted for $9.2 \%$ and $20.0 \%$ of the total $\mathrm{Cd}$ in the soil, accounting for $34.3 \%$ and $74.3 \%$ of the sum of the exchangeable and carbonate-bound Cd. In B. cereus, only $0.04 \mathrm{mg} / \mathrm{kg} \mathrm{Cd}$ was dissolved after being cultured for 1 day compared with the non-inoculated control. This amount was $2.0 \%$ of the total $\mathrm{Cd}$ and $7.6 \%$ of the sum of the exchangeable and carbonate-bound $\mathrm{Cd}$. The amount of dissolved $\mathrm{Cd}$ in B. cereus for 7 days was close to that of the control group.

Ma et al. reported that Psychrobacter sp. SRS8 and B. cereus SRA10 mobilized 16 and $12 \mathrm{mg} / \mathrm{kg} \mathrm{Ni}$ in soil [44,45]. Rajkumar et al. observed that Pseudomonas sp. PsM6 and Bacillus weihenstephanesis SM3 mobilized 14 and $8 \mathrm{mg} / \mathrm{kg} \mathrm{Zn}$ in soil, respectively [46,47]. In the present study, high-Cd-mobilizing PSB P. fluorescens promoted the release of $0.39 \mathrm{mg} / \mathrm{kg}$ Cd from the Cd-polluted soil, which could have the potential to enhance the extraction of Cd by plants. He et al. reported that Rahnella sp. JN6 increased $0.46 \mathrm{mg} / \mathrm{kg}$ Cd in B. napus rhizosphere soil, which doubled the content of Cd in the plant [30]. Jiang et al. reported that Burkholderia sp. J62 increased $0.50 \mathrm{mg} / \mathrm{kg} \mathrm{Cd}$ in maize rhizosphere soil and $0.88 \mathrm{mg} / \mathrm{kg} \mathrm{Cd}$ in tomato rhizosphere soil, which greatly increased the uptake of $\mathrm{Cd}$ in maize root and tomato shoot [31].

\subsection{Metabolite Analysis and Their Cd-Solubilizing Abilities}

P. fluorescens and B. cereus grew well in the nutrient-rich liquid medium with $\mathrm{CdCO}_{3}$ on culture day 1. Therefore, we selected this culture solution for further secretions analysis. A total of 34 secretions were identified by GC-MS (Table S3). Mann-Whitney U test analysis showed that there were significant $(p<0.05)$ differences in the secretions of B. cereus and P. fluorescens except glycerol and ribose. In B. cereus, the majority of secretions were monosaccharides, followed by organic acid. In P. fluorescens, the major secretions were organic acids.

Table 3 showed the concentrations of organic acids and their Cd-solubilizing abilities. The secretion of $P$. fluorescens was mostly composed of gluconic acid, which can dissolve $13.1 \mathrm{mg} / \mathrm{L}$ $\mathrm{Cd}$, followed by oxalic acid. On the other hand, the secretion of $B$. cereus was mostly comprised of pyruvic acid, which can dissolve $4.52 \mathrm{mg} / \mathrm{L} \mathrm{Cd}$, followed by glycolic acid. The total concentrations of Cd solubilized by all the secreted organic acids in B. cereus and P. fluorescens equaled 19.2 and $30.8 \mathrm{mg} / \mathrm{L}$, respectively, which were similar to Cd concentrations (16.94 and $29.96 \mathrm{mg} / \mathrm{L}$, respectively) in the nutrient-rich medium after 1 day of inoculation (Table 1). This indicated that the calculated results of the $\mathrm{Cd}$-solubilizing abilities of the secreted organic acids were consistent with the actual detected results. The high solubilizing effect of $P$. fluorescens for $\mathrm{Cd}$ mainly resulted from large amounts of gluconic acid (75.9\% of the total organic acid concentration) and oxalic acid (7.0\% of the total organic acid concentration) produced (Table 3). The amount of Cd solubilized by gluconic acid and oxalic acid reached $42.4 \%$ and $24.4 \%$, respectively, of the total concentration of Cd solubilized by $P$. fluorescens. This was consistent with previous findings that the Pseudomonas species release P from sparingly soluble mineral phosphates by producing high levels of gluconic acid from extracellular glucose $[48,49]$. 
Table 2. Effect of B. cereus and P. fluorescens on cadmium mobility in Cd-polluted soil.

\begin{tabular}{|c|c|c|c|c|c|c|c|c|c|c|}
\hline \multirow{2}{*}{ Treatment } & \multicolumn{5}{|c|}{1 Day } & \multicolumn{5}{|c|}{7 Days } \\
\hline & $\begin{array}{c}\text { Dissolved } \\
\mathrm{Cd}^{2+}(\mathrm{mg} / \mathrm{kg} \\
\text { Dry Soil) }\end{array}$ & $\mathrm{pH}$ & $\begin{array}{c}\text { Net } \\
\text { Dissolved } \\
\mathrm{Cd}^{2+}(\mathrm{mg} / \mathrm{kg} \\
\text { Dry Soil })\end{array}$ & $\begin{array}{c}\text { Ratio of Net } \\
\text { Dissolved } \mathrm{Cd}^{2+} \\
\text { to Total } \\
\text { Cadmium in } \\
\text { Soil } \\
\end{array}$ & $\begin{array}{l}\text { Ratio of Net } \\
\text { Dissolved Cd }{ }^{2+} \text { to } \\
\text { the Exchangeable } \\
\text { and Carbonate- } \\
\text { Bound Cadmium }\end{array}$ & $\begin{array}{c}\text { Dissolved } \\
\mathrm{Cd}^{2+}(\mathrm{mg} / \mathrm{kg} \\
\text { Dry Soil })\end{array}$ & $\mathrm{pH}$ & $\begin{array}{l}\text { Net Dissolved } \\
\mathrm{Cd}^{2+}(\mathrm{mg} / \mathrm{kg} \text { Dry } \\
\text { Soil) }\end{array}$ & $\begin{array}{c}\text { Ratio of Net } \\
\text { Dissolved Cd } \mathrm{Cd}^{2+} \\
\text { to Total } \\
\text { Cadmium in Soil }\end{array}$ & $\begin{array}{l}\text { Ratio of Net } \\
\text { Dissolved Cd } \mathrm{Cd}^{2+} \text { to } \\
\text { the Exchangeable } \\
\text { and Carbonate- } \\
\text { Bound Cadmium }\end{array}$ \\
\hline B. cereus & $0.08 \pm 0.03^{a}$ & $6.55 \pm 0.07^{b}$ & 0.04 & $2.0 \%$ & $7.6 \%$ & $0.03 \pm 0.01^{\mathrm{a}}$ & $6.66 \pm 0.09^{b}$ & - & - & - \\
\hline P. fluorescens & $0.22 \pm 0.03^{\mathrm{b}}$ & $4.42 \pm 0.05^{\mathrm{a}}$ & 0.18 & $9.2 \%$ & $34.3 \%$ & $0.43 \pm 0.08^{b}$ & $4.46 \pm 0.18^{a}$ & 0.39 & $20.0 \%$ & $74.3 \%$ \\
\hline
\end{tabular}

Data are expressed as mean \pm SD of three replicates $(n=3)$. Different small letters in each column indicate significant differences at $p<0.05$ in the ANOVA Duncan test. The net dissolved

$\mathrm{Cd}$ is equal to the dissolved $\mathrm{Cd}$ in the experimental group minus the dissolved $\mathrm{Cd}$ in the control group.

Table 3. Concentration and Cd-solubilizing ability of organic acids.

\begin{tabular}{|c|c|c|c|c|}
\hline Organic acid & $\begin{array}{l}\text { Concentration in } \\
\text { B. cereus }(\mathrm{mg} / \mathrm{L})\end{array}$ & $\begin{array}{c}\text { Cd-Solubilizing Ability in } \\
\text { B. cereus }(\mathrm{mg} / \mathrm{L})\end{array}$ & $\begin{array}{c}\text { Concentration in } \\
P . \text { fluorescens }(\mathrm{mg} / \mathrm{L})\end{array}$ & $\begin{array}{l}\text { Cd-Solubilizing Ability in } \\
\text { P. fluorescens }(\mathrm{mg} / \mathrm{L})\end{array}$ \\
\hline Pyruvic acid & 9.738 & 4.52 & n. d. & n. d. \\
\hline Lactic acid & 1.988 & 2.11 & 1.193 & 1.80 \\
\hline Glycolic acid & 5.382 & 2.95 & 0.339 & - \\
\hline Oxalic acid & n. d. & n. d. & 6.962 & 7.52 \\
\hline 3-Hydroxy butyric acid & 0.783 & - & n. d. & n. d. \\
\hline Succinic acid & 1.098 & 2.28 & 0.854 & - \\
\hline Glyceric acid & 0.998 & - & 0.431 & - \\
\hline Gluconic acid & n. d. & n. d. & 75.315 & 13.08 \\
\hline Erythronic acid & 2.120 & 1.51 & 5.260 & 2.22 \\
\hline Ribonic acid & 3.242 & 1.77 & 3.554 & 1.84 \\
\hline 3-Hydroxy propionic acid & 0.087 & - & n. d. & n. d. \\
\hline 2,4-Dihydroxy butanoic acid & 1.346 & 1.34 & 2.203 & 1.53 \\
\hline 3,4-Dihydroxy butanoic acid & 1.255 & 1.32 & 2.084 & 1.57 \\
\hline Hexadecanoic acid & 1.466 & 1.38 & 1.079 & 1.26 \\
\hline
\end{tabular}

The "-" means the concentration of organic acid was not suitable for calculating the Cd-solubilizing ability, because its value was lower than the minimum value (1 mg/L) of the soluble cadmium capacity curve. The Cd-solubilizing ability of the organic acids refers to the amount of cadmium $\left(\mathrm{CdCO}_{3}\right)$ dissolved under the corresponding organic acid concentration (Figure S3). 


\subsection{Metabolic Pathway Analysis}

Based on the previous literature [49] and the Kyoto Encyclopedia of Genes and Genomes (KEGG) database [50], lactic acid and pyruvic acid were mainly produced by glycolysis. Succinic acid was produced by TCA cycle. Gluconic acid was produced through the periplasmic direct oxidation pathway and the pentose phosphate pathway. Glycolic acid and oxalic acid were produced through the glyoxylate and dicarboxylate metabolism. Therefore, the major metabolites secreted by the two strains were mainly produced by carbon metabolism, and their primary metabolic networks compiled from KEGG were presented in Figures 1 and 2, respectively.

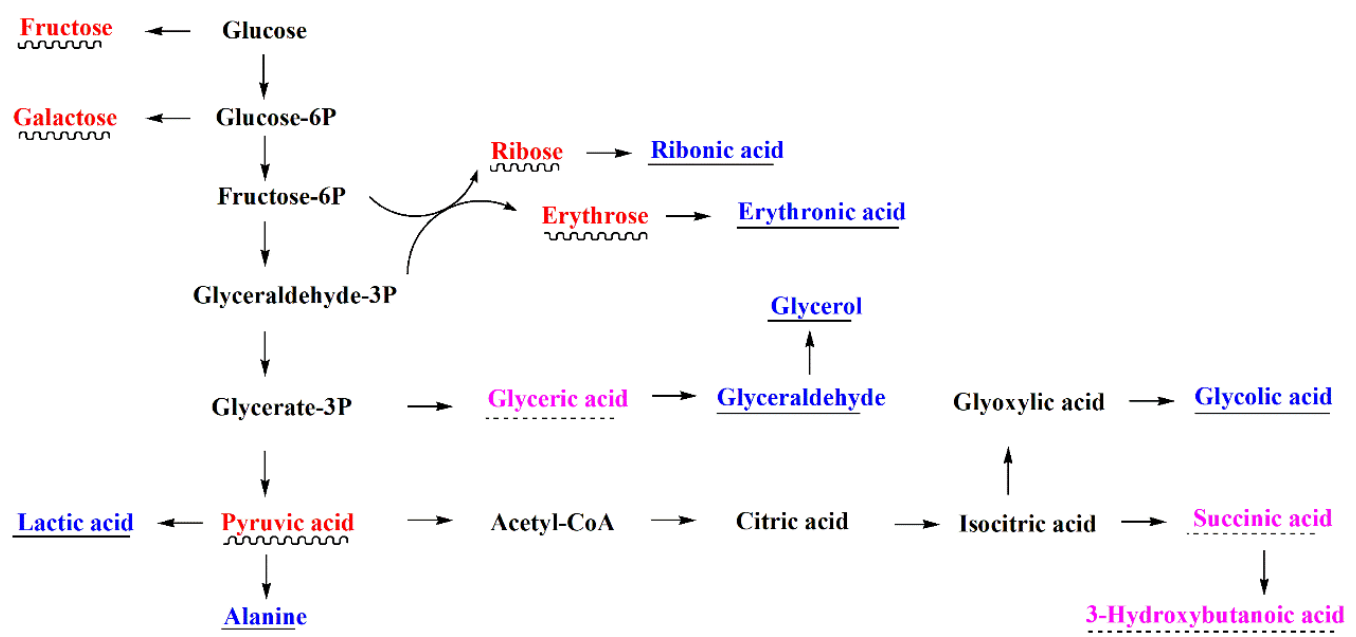

Figure 1. The primary metabolism showing the major compounds that were detected in B. cereus qh-35. The red-labeled and wavy-line-underscored metabolites are those in large quantities. The blue-labeled and straight-line-underscored metabolites are those in moderate quantities. The purple-labeled and dotted-line-underscored metabolites are those in small quantities.

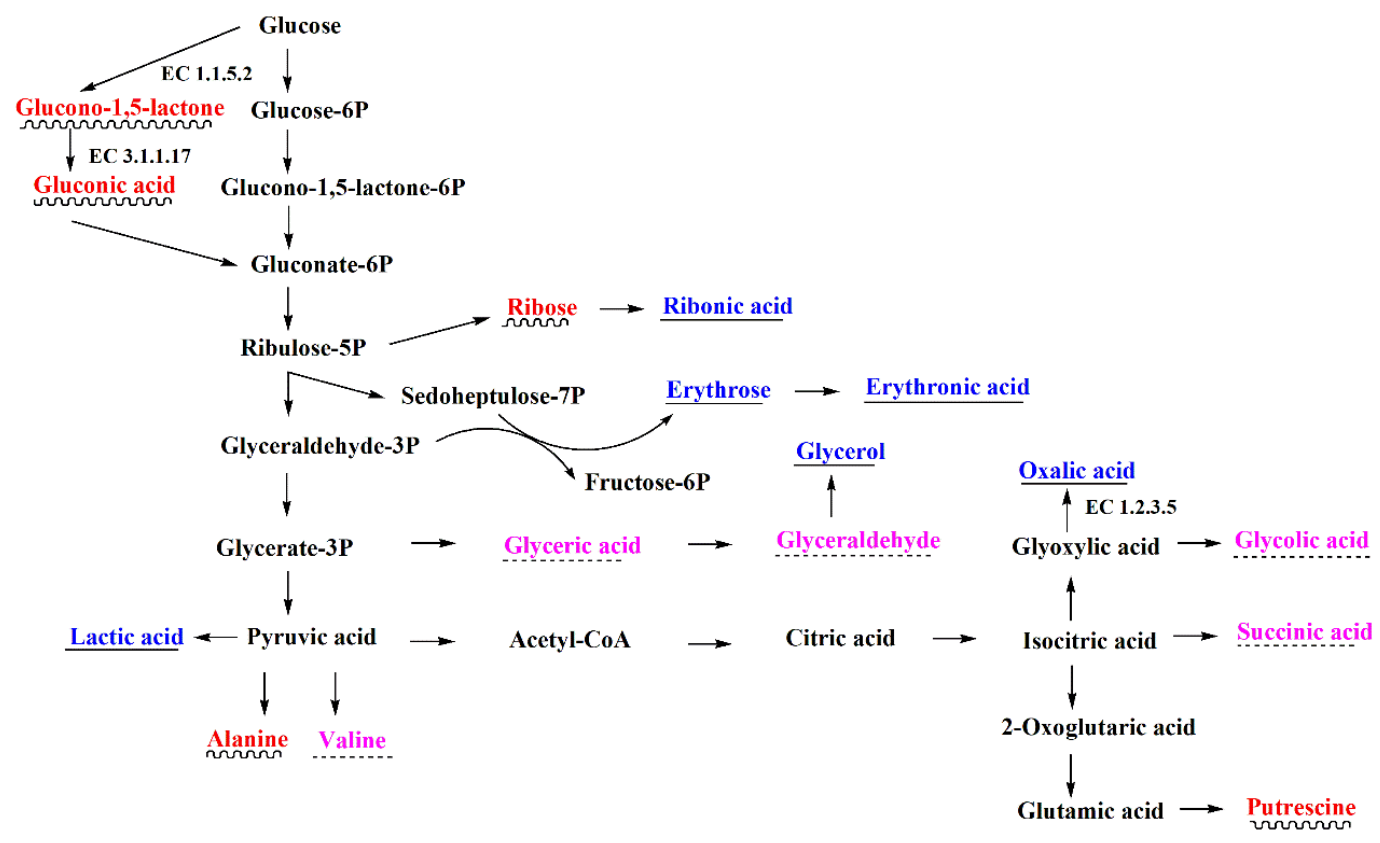

Figure 2. The primary metabolism showing the major compounds that were detected in P. fluorescens gim-3. The red-labeled and wavy-line-underscored metabolites are those in large quantities. The blue-labeled and straight-line-underscored metabolites are those in moderate quantities. The purple-labeled and dotted-line-underscored metabolites are those in small quantities. 
Figures 1 and 2 showed that glucose catabolism was considerably different between $B$. cereus and P. fluorescens. B. cereus produced energy and intermediates for biosynthesis through glycolysis, which was similar to Bacillus sp. [49]. A large amount of pyruvic acid was produced by glycolysis. However, P. fluorescens converted extracellular glucose to gluconic acid, as in previous studies [51,52]. Generally, two glucose 1-dehydrogenases (EC 1.1.5.2 and EC 1.1.1.47) can convert glucose into gluconolactone, which was further hydrolyzed by gluconolactonase (EC 3.1.1.17) into gluconic acid. EC 1.1.5.2 occurred in the periplasm and was controlled by the $g c d$ gene [53-56], while EC 1.1.1.47 occurred in the intracellular and was controlled by the $g d h$ gene. They were involved in the periplasmic direct oxidation pathway and the pentose phosphate pathway, respectively. In P-limiting conditions, the direct oxidation pathway predominated in the Pseudomonas species [48]. In present study, glucose was not detected in the culture medium of P. fluorescens gim-3, but a large amount of gluconic acid was detected (Table S3). This indicated that the conversion of glucose was very fast. This can only be achieved by extracellular oxidation. Therefore, in P. fluorescens gim-3, glucose catabolism primarily occurred through the periplasmic direct oxidation pathway. The isolated strain of P. fluorescens gim-3 could produce EC 1.1.5.2 and EC 3.1.1.17, but B. cereus qh-35 could not produce them.

Furthermore, the products of glyoxylate and dicarboxylate metabolism of B. cereus and P. fluorescens were different (Figures 1 and 2). P. fluorescens can produce oxalic acid and glycolic acid. However, B. cereus only produced glycolic acid. Therefore, the strain of P. fluorescens gim-3 isolated in this study might have glyoxylate oxidase (EC 1.2.3.5).

\section{Conclusions}

In this study, two PSB strains were isolated from the soil. Their metabolism and abilities to solubilize carbonate $\mathrm{Cd}$ and soil $\mathrm{Cd}$ were investigated. P. fluorescens gim-3, a high-Cd-mobilizing PSB, secreted large amounts of gluconic acid and dissolved more Cd. B. cereus qh-35, a low-Cd-mobilizing PSB, did not secrete gluconic acid and dissolved less Cd. Metabolic pathway analysis in bacteria showed that gluconic acid in P. fluorescens gim-3 was produced by the peripheral direct oxidation pathway, which was controlled by EC 1.1.5.2 and EC 3.1.1.17. Therefore, PSB with the peripheral direct oxidation pathway were likely to have high-Cd-mobilizing ability. PSB, by increasing cadmium mobility, may increase metal toxicity to flora and fauna, for example, on various invertebrates that have skin in contact with moist soil (such as eisenia) or even vertebrate eggs with semi-permeable shell (such as lizards). Further research will be conducted on this issue in the future.

Supplementary Materials: The following are available online at http:/ /www.mdpi.com/1660-4601/15/7/1330/ s1, Figure S1: Colony morphology of Bacillus cereus qh-35, Figure S2: Colony morphology of Pseudomonas fluorescens gim-3, Figure S3: Curve of the cadmium $\left(\mathrm{CdCO}_{3}\right)$ solubilization ability of organic acids, Table S1: The physiological and biochemical reactions of Bacillus cereus qh-35, Table S2: The physiological and biochemical reactions of Pseudomonas fluorescens gim-3, Table S3: Secretions of B. cereus and P. fluorescens, Text S1: The 16S rDNA gene sequences of Bacillus cereus qh-35, Text S2: The 16S rDNA gene sequences of Pseudomonas fluorescens gim-3.

Author Contributions: Q.-S.L. conceived and designed the study. X.-F.Z. and T.Z. performed the survey. P.Y. analyzed the data and wrote the paper. L.-L.W. and B.-Y.H. managed and coordinated the research activity planning and execution. Y.-K.C. and Z.-Y.Z. performed statistical analysis.

Funding: This work was supported by the National Natural Science Foundation of China [grant numbers 41673094 and 41701349]; the Department of Science and Technology of Guangdong Province, China [grant number 2016A020221015]; and the National Key Research Project of China [grant number 2017YFD0801305].

Conflicts of Interest: The authors declare no conflict of interest.

\section{References}

1. Järup, L.; Åkesson, A. Current status of cadmium as an environmental health problem. Toxicol. Appl. Pharmacol. 2009, 238, 201-208. [CrossRef] [PubMed]

2. Nawrot, T.; Plusquin, M.; Hogervorst, J.; Roels, H.A.; Celis, H.; Thijs, L.; Vangronsveld, J.; Van Hecke, E.; Staessen, J.A. Environmental exposure to cadmium and risk of cancer: A prospective population-based study. Lancet Oncol. 2006, 7, 119-126. [CrossRef] 
3. World Health Organization. Exposure to Cadmium: A Major Public Health Concern. Available online: http:/ / www.who.int/ipcs/assessment/public_health/cadmium/en (accessed on 30 May 2018).

4. Satarug, S.; Garrett, S.H.; Sens, M.A.; Sens, D.A. Cadmium, environmental exposure, and health outcomes. Environ. Health Perspect. 2010, 118, 182-190. [CrossRef] [PubMed]

5. He, S.; He, Z.; Yang, X.; Stoffella, P.J.; Baligar, V.C. Chapter 4-Soil biogeochemistry, plant physiology, and phytoremediation of cadmium-contaminated soils. In Advances in Agronomy; Donald, L.S., Ed.; Academic Press: Cambridge, MA, USA, 2015; Volume 134, pp. 135-225.

6. Prasad, M.N.V.; Freitas, H.; Fraenzle, S.; Wuenschmann, S.; Markert, B. Knowledge explosion in phytotechnologies for environmental solutions. Environ. Pollut. 2010, 158, 18-23. [CrossRef] [PubMed]

7. Suresh, B.; Ravishankar, G.A. Phytoremediation-A novel and promising approach for environmental clean-up. Crit. Rev. Biotechnol. 2004, 24, 97-124. [CrossRef] [PubMed]

8. Surriya, O.; Sarah Saleem, S.; Waqar, K.; Gul Kazi, A. Chapter 1-Phytoremediation of soils: Prospects and challenges. In Soil Remediation and Plants; Hakeem, K.R., Sabir, M., Öztürk, M., Mermut, A.R., Eds.; Academic Press: San Diego, CA, USA, 2015; pp. 1-36.

9. Ali, H.; Khan, E.; Sajad, M.A. Phytoremediation of heavy metals-Concepts and applications. Chemosphere 2013, 91, 869-881. [CrossRef] [PubMed]

10. Ahemad, M.; Kibret, M. Mechanisms and applications of plant growth promoting rhizobacteria: Current perspective. JKSUS 2014, 26, 1-20. [CrossRef]

11. Glick, B.R. Using soil bacteria to facilitate phytoremediation. Biotechnol. Adv. 2010, 28, 367-374. [CrossRef] [PubMed]

12. Ma, Y.; Prasad, M.N.V.; Rajkumar, M.; Freitas, H. Plant growth promoting rhizobacteria and endophytes accelerate phytoremediation of metalliferous soils. Biotechnol. Adv. 2011, 29, 248-258. [CrossRef] [PubMed]

13. Rajkumar, M.; Ae, N.; Prasad, M.N.V.; Freitas, H. Potential of siderophore-producing bacteria for improving heavy metal phytoextraction. Trends Biotechnol. 2010, 28, 142-149. [CrossRef] [PubMed]

14. Ullah, A.; Heng, S.; Munis, M.F.H.; Fahad, S.; Yang, X. Phytoremediation of heavy metals assisted by plant growth promoting (PGP) bacteria: A review. Environ. Exper. Bot. 2015, 117, 28-40. [CrossRef]

15. Ma, Y.; Oliveira, R.S.; Nai, F.; Rajkumar, M.; Luo, Y.; Rocha, I.; Freitas, H. The hyperaccumulator Sedum plumbizincicola harbors metal-resistant endophytic bacteria that improve its phytoextraction capacity in multi-metal contaminated soil. J. Environ. Manag. 2015, 156, 62-69. [CrossRef] [PubMed]

16. Chen, L.; Luo, S.; Li, X.; Wan, Y.; Chen, J.; Liu, C. Interaction of cd-hyperaccumulator Solanum nigrum L. and functional endophyte Pseudomonas sp. Lk9 on soil heavy metals uptake. Soil Biol. Biochem. 2014, 68, 300-308. [CrossRef]

17. Luo, S.; Xu, T.; Chen, L.; Chen, J.; Rao, C.; Xiao, X.; Wan, Y.; Zeng, G.; Long, F.; Liu, C.; et al. Endophyte-assisted promotion of biomass production and metal-uptake of energy crop sweet sorghum by plant-growth-promoting endophyte Bacillus sp. Sls18. Appl. Microbiol. Biotechnol. 2012, 93, 1745-1753. [CrossRef] [PubMed]

18. Sharma, R.K.; Archana, G. Cadmium minimization in food crops by cadmium resistant plant growth promoting rhizobacteria. Appl. Soil Ecol. 2016, 107, 66-78. [CrossRef]

19. Dimkpa, C.O.; Merten, D.; Svatoš, A.; Büchel, G.; Kothe, E. Siderophores mediate reduced and increased uptake of cadmium by Streptomyces tendae $\mathrm{f} 4$ and sunflower (Helianthus annuus), respectively. J. Appl. Microbiol. 2009, 107, 1687-1696. [CrossRef] [PubMed]

20. He, L.-Y.; Chen, Z.-J.; Ren, G.-D.; Zhang, Y.-F.; Qian, M.; Sheng, X.-F. Increased cadmium and lead uptake of a cadmium hyperaccumulator tomato by cadmium-resistant bacteria. Ecotoxicol. Environ. Saf. 2009, 72, 1343-1348. [CrossRef] [PubMed]

21. Sheng, X.-F.; Xia, J.-J. Improvement of rape (Brassica napus) plant growth and cadmium uptake by cadmium-resistant bacteria. Chemosphere 2006, 64, 1036-1042. [CrossRef] [PubMed]

22. Sinha, S.; Mukherjee, S.K. Cadmium-induced siderophore production by a high cd-resistant bacterial strain relieved cd toxicity in plants through root colonization. Curr. Microbiol. 2008, 56, 55-60. [CrossRef] [PubMed]

23. Guo, J.; Lei, M.; Yang, J.; Yang, J.; Wan, X.-M.; Chen, T.-B.; Zhou, X.-Y.; Gu, S.-P.; Guo, G.-H. Effect of fertilizers on the Cd uptake of two sedum species (Sedum spectabile Boreau and Sedum aizoon L.) as potential Cd accumulators. Ecol. Eng. 2017, 106, 409-414. [CrossRef]

24. Ahemad, M. Phosphate-solubilizing bacteria-assisted phytoremediation of metalliferous soils: A review. 3 Biotech 2015, 5, 111-121. [CrossRef] [PubMed] 
25. Chen, Y.P.; Rekha, P.D.; Arun, A.B.; Shen, F.T.; Lai, W.A.; Young, C.C. Phosphate solubilizing bacteria from subtropical soil and their tricalcium phosphate solubilizing abilities. Appl. Soil Ecol. 2006, 34, 33-41. [CrossRef]

26. Gulati, A.; Sharma, N.; Vyas, P.; Sood, S.; Rahi, P.; Pathania, V.; Prasad, R. Organic acid production and plant growth promotion as a function of phosphate solubilization by Acinetobacter rhizosphaerae strain BIHB 723 isolated from the cold deserts of the trans-Himalayas. Arch. Microbiol. 2010, 192, 975-983. [CrossRef] [PubMed]

27. Stefanoni Rubio, P.J.; Godoy, M.S.; Della Mónica, I.F.; Pettinari, M.J.; Godeas, A.M.; Scervino, J.M. Carbon and nitrogen sources influence tricalcium phosphate solubilization and extracellular phosphatase activity by talaromyces flavus. Curr. Microbiol. 2016, 72, 41-47. [CrossRef] [PubMed]

28. Guo, J.; Tang, S.; Ju, X.; Ding, Y.; Liao, S.; Song, N. Effects of inoculation of a plant growth promoting rhizobacterium Burkholderia sp. D54 on plant growth and metal uptake by a hyperaccumulator Sedum alfredii Hance grown on multiple metal contaminated soil. World J. Microbiol. Biotechnol. 2011, 27, 2835-2844. [CrossRef]

29. Jeong, S.; Moon, H.S.; Nam, K.; Kim, J.Y.; Kim, T.S. Application of phosphate-solubilizing bacteria for enhancing bioavailability and phytoextraction of cadmium (Cd) from polluted soil. Chemosphere 2012, 88, 204-210. [CrossRef] [PubMed]

30. He, H.; Ye, Z.; Yang, D.; Yan, J.; Xiao, L.; Zhong, T.; Yuan, M.; Cai, X.; Fang, Z.; Jing, Y. Characterization of endophytic Rahnella sp. Jn6 from Polygonum pubescens and its potential in promoting growth and $\mathrm{Cd}, \mathrm{Pb}$, Zn uptake by Brassica napus. Chemosphere 2013, 90, 1960-1965. [CrossRef] [PubMed]

31. Jiang, C.-Y.; Sheng, X.-F.; Qian, M.; Wang, Q.-Y. Isolation and characterization of a heavy metal-resistant Burkholderia sp. From heavy metal-contaminated paddy field soil and its potential in promoting plant growth and heavy metal accumulation in metal-polluted soil. Chemosphere 2008, 72, 157-164. [CrossRef] [PubMed]

32. Sharma, S.B.; Sayyed, R.Z.; Trivedi, M.H.; Gobi, T.A. Phosphate solubilizing microbes: Sustainable approach for managing phosphorus deficiency in agricultural soils. SpringerPlus 2013, 2, 587. [CrossRef] [PubMed]

33. Vyas, P.; Gulati, A. Organic acid production in vitro and plant growth promotion in maize under controlled environment by phosphate-solubilizing fluorescent Pseudomonas. BMC Microbiol. 2009, 9, 174. [CrossRef] [PubMed]

34. Tessier, A.; Campbell, P.G.C.; Bisson, M. Sequential extraction procedure for the speciation of particulate trace metals. Anal. Chem. 1979, 51, 844-851. [CrossRef]

35. Fiehn, O.; Kopka, J.; Trethewey, R.N.; Willmitzer, L. Identification of Uncommon Plant Metabolites Based on Calculation of Elemental Compositions Using Gas Chromatography and Quadrupole Mass Spectrometry. Anal. Chem. 2000, 72, 3573-3580. [CrossRef] [PubMed]

36. Ute, R.; Cornelia, W.; Joachim, K.; Richard, N.T.R.; Lothar, W. Simultaneous analysis of metabolites in potato tuber by gas chromatography-mass spectrometry. Plant J. 2000, 23, 131-142.

37. Halket, J.M.; Przyborowska, A.; Stein, S.E.; Mallard, W.G.; Down, S.; Chalmers, R.A. Deconvolution gas chromatography/mass spectrometry of urinary organic acids-Potential for pattern recognition and automated identification of metabolic disorders. Rapid Commun. Mass Spectrom. 1999, 13, 279-284. [CrossRef]

38. Stein, S.E. An integrated method for spectrum extraction and compound identification from gas chromatography/mass spectrometry data. J. Am. Soc. Mass Spectrom. 1999, 10, 770-781. [CrossRef]

39. Katsumasa, S.; Keiki, O.; Keitaro, T.; Mitsuru, O.; Takuro, S. Gas chromatography-mass spectrometry associated global analysis of rice root exudates under aseptical conditions. Soil Sci. Plant Nutr. 2009, 55, 505-513.

40. Okazaki, K.; Oka, N.; Shinano, T.; Osaki, M.; Takebe, M. Differences in the Metabolite Profiles of Spinach (Spinacia oleracea L.) Leaf in Different Concentrations of Nitrate in the Culture Solution. Plant and Cell Physiol. 2008, 49, 170-177. [CrossRef] [PubMed]

41. Erban, A.; Schauer, N.; Fernie, A.R.; Kopka, J. Nonsupervised Construction and Application of Mass Spectral and Retention Time Index Libraries from Time-of-Flight Gas Chromatography-Mass Spectrometry Metabolite Profiles. In Metabolomics: Methods and Protocols; Weckwerth, W., Ed.; Humana Press: Totowa, NJ, USA, 2007; Volume 358, pp. 19-38.

42. Kumari, A.; Parida, A.K. Metabolomics and network analysis reveal the potential metabolites and biological pathways involved in salinity tolerance of the halophyte Salvadora persica. Environ. Exper. Bot. 2018, 148, 85-99. [CrossRef] 
43. Li, K.; Ramakrishna, W. Effect of multiple metal resistant bacteria from contaminated lake sediments on metal accumulation and plant growth. J. Hazard. Mater. 2011, 189, 531-539. [CrossRef] [PubMed]

44. Ma, Y.; Rajkumar, M.; Freitas, H. Isolation and characterization of Ni mobilizing PGPB from serpentine soils and their potential in promoting plant growth and Ni accumulation by Brassica spp. Chemosphere 2009, 75, 719-725. [CrossRef] [PubMed]

45. Ma, Y.; Rajkumar, M.; Freitas, H. Improvement of plant growth and nickel uptake by nickel resistant-plant-growth promoting bacteria. J. Hazard. Mater. 2009, 166, 1154-1161. [CrossRef] [PubMed]

46. Rajkumar, M.; Freitas, H. Influence of metal resistant-plant growth-promoting bacteria on the growth of ricinus communis in soil contaminated with heavy metals. Chemosphere 2008, 71, 834-842. [CrossRef] [PubMed]

47. Rajkumar, M.; Ma, Y.; Freitas, H. Characterization of metal-resistant plant-growth promoting Bacillus weihenstephanensis isolated from serpentine soil in Portugal. J. Basic Microbiol. 2008, 48, 500-508. [CrossRef] [PubMed]

48. Buch, A.; Archana, G.; Naresh Kumar, G. Metabolic channeling of glucose towards gluconate in phosphate-solubilizing Pseudomonas aeruginosa p4 under phosphorus deficiency. Res. Microbiol. 2008, 159, 635-642. [CrossRef] [PubMed]

49. Fuhrer, T.; Fischer, E.; Sauer, U. Experimental identification and quantification of glucose metabolism in seven bacterial species. J. Bacteriol. 2005, 187, 1581-1590. [CrossRef] [PubMed]

50. KEGG PATHWAY Database. Available online: http://www.genome.jp/kegg/pathway.html (accessed on 30 May 2018).

51. Buch, A.; Archana, G.; Naresh Kumar, G. Heterologous expression of phosphoenolpyruvate carboxylase enhances the phosphate solubilizing ability of fluorescent pseudomonads by altering the glucose catabolism to improve biomass yield. Bioresour. Technol. 2010, 101, 679-687. [CrossRef] [PubMed]

52. Nikel, P.I.; Chavarría, M.; Fuhrer, T.; Sauer, U.; de Lorenzo, V. Pseudomonas putida kt2440 Strain Metabolizes Glucose through a Cycle Formed by Enzymes of the Entner-Doudoroff, Embden-Meyerhof-Parnas, and Pentose Phosphate Pathways. J. Biol. Chem. 2015, 290, 25920-25932. [CrossRef] [PubMed]

53. Buch, A.D.; Archana, G.; Kumar, G.N. Enhanced citric acid biosynthesis in Pseudomonas fluorescens ATCC 13525 by overexpression of the Escherichia coli citrate synthase gene. Microbiology 2009, 155, 2620-2629. [CrossRef] [PubMed]

54. Ludueña, L.M.; Anzuay, M.S.; Magallanes-Noguera, C.; Tonelli, M.L.; Ibañez, F.J.; Angelini, J.G.; Fabra, A.; McIntosh, M.; Taurian, T. Effects of P limitation and molecules from peanut root exudates on $p q q E$ gene expression and $p q q$ promoter activity in the phosphate-solubilizing strain Serratia sp. S119. Res. Microbiol. 2017, 168, 710-721. [CrossRef] [PubMed]

55. Mustafa, G.; Ishikawa, Y.; Kobayashi, K.; Migita, C.T.; Elias, M.D.; Nakamura, S.; Tagawa, S.; Yamada, M. Amino acid residues interacting with both the bound quinone and coenzyme, pyrroloquinoline quinone, in Escherichia coli membrane-bound glucose dehydrogenase. J. Biol. Chem. 2008, 283, 22215-22221. [CrossRef] [PubMed]

56. Rodriguez, H.; Fraga, R. Phosphate solubilizing bacteria and their role in plant growth promotion. Biotechnol. Adv. 1999, 17, 319-339. [CrossRef]

(C) 2018 by the authors. Licensee MDPI, Basel, Switzerland. This article is an open access article distributed under the terms and conditions of the Creative Commons Attribution (CC BY) license (http://creativecommons.org/licenses/by/4.0/). 